\title{
Disproportionating Transglycosylase (D-Enzyme) in Green Algae and Cyanobacteria. Partial Purification and Characterization
}

\author{
Birgit Fuchs, Petra Suttner, Sabine Sterner, Robert Wastlhuber and Eckhard Loos \\ Lehrstuhl für Zellbiologie und Pflanzenphysiologie, Universität Regensburg, \\ D-93040 Regensburg, Bundesrepublik Deutschland \\ Z. Naturforsch. 49c, 163-170 (1994); received December 16, 1993/February 18, 1994 \\ Cyanobacteria, D-Enzyme, Green Algae, Symbiosis \\ D-Enzyme (4- $\alpha$-glucanotransferase, EC 2.4.1.25) from cultured symbiotic Nostoc and Chlo- \\ rella has been partially purified and characterized. The enzyme catalyzes the disproportiona- \\ tion of maltooligosaccharides and is able to form maltooligosaccharides from soluble starch \\ and D-glucose. The properties of D-enzyme from Nostoc and Chlorella are similar with respect \\ to substrate specificity, $K_{\mathrm{M}}$ values and $\mathrm{pH}$ dependence, but differ with respect to temperature \\ optimum and molecular weight $\left(40^{\circ} \mathrm{C} / 50 \mathrm{kDa}\right.$ and $50^{\circ} \mathrm{C} / 230 \mathrm{kDa}$ for the enzyme from \\ Nostoc and Chlorella, respectively). D-enzyme activity has been demonstrated also in free- \\ living Anabaena, Chlorella and Chlamydomonas. Its physiological role in symbiotic Nostoc is \\ briefly discussed.
}

\section{Introduction}

D-Enzyme is a transglycosylase disproportionating maltooligosaccharides in chain length, e.g. forming glucose and maltopentaose from two molecules of maltotriose by a maltosyltransfer (Peat et al., 1956; Jones and Whelan, 1969). It's suggested physiological role is to provide maltooligosaccharides sufficiently long for phosphorolytic breakdown from those too short (degree of polymerization $(\mathrm{DP}) \leq 4)$ to be a substrate for phosphorylase (Lee et al., 1970; Kakefuda et al., 1986). Activity of D-enzyme has been shown in several higher plants where it has been found in different organs (Peat et al., 1956; Kakefuda et al., 1986; Manners and Rowe, 1969; Okita et al., 1979).

Since in the disproportionation of maltodextrins by D-enzyme free glucose appears as a reaction product, this reaction may be important for symbiotic phototrophs providing their host with glucose as do e.g. the cyanobacterial photobionts of lichens (Drew and Smith, 1967; Hill and Smith, 1972). In the present work D-enzyme from the cultivated cyanobiont, a Nostoc sp., of the lichen Peltigera horizontalis was partially purified and cha-

Abbreviations: DP, degree of polymerization; EDTA, ethylenediaminetetraacetic acid; SDS, sodium dodecyl sulfate.

Reprint requests to Dr. E. Loos.

Verlag der Zeitschrift für Naturforschung,

D-72072 Tübingen

0939-5075/94/0300-0163 \$03.00/0 racterized, and, in addition, from a Chlorella sp. isolated from the heliozoon Acanthocystis turfa$c e a$. To see whether disproportionating transglycosylase is of more general occurrence, tests were made for this enzyme also with cell-free extracts of two free-living strains of green algae and of a freeliving cyanobacterium.

\section{Materials and Methods}

\section{Plant material}

Nostoc sp. isolated from the lichen Peltigera horizontalis (Meindl and Loos, 1990) was cultured in medium BG 11 of Stanier et al. (1971) in which $\mathrm{NaNO}_{3}$ was substituted by $\mathrm{NaCl}(1 \mathrm{~mm})$. Other culture conditions were as those used by Fischer et al. (1989). Filaments were harvested 7-13 d after inoculation in the beginning stationary phase (Bogner et al., 1993).

Anabaena sp. strain PCC 7120 originated from the culture collection of Dr. P. Wolk (East Lansing, U.S.A.) and was cultured and harvested as Nostoc. From Sammlung für Algenkulturen Göttingen, F.R.G. were obtained Chlamydomonas noctigama strain 35.72 and Chlorella sp. strain 3.83 which is the endosymbiont of the heliozoon Acanthocystis turfacea. Chlorella kessleri was kindly supplied by Dr. N. Sauer from our institute. Liquid mineral medium according to Matzke et al. (1990) and Kuhl (1962) was used for growing Chlorella sp. 3.83 and the other strains of green algae, respectively. Other conditions were as de- 
scribed previously (Fischer et al., 1989). Cells of Chlorella and Chlamydomonas were collected by centrifugation 4-5 d after inoculation when cell densities between 2.0 and $4.0 \mu \mathrm{l}$ packed cells $\cdot \mathrm{ml}^{-1}$ had been obtained.

\section{Purification of D-enzyme; estimation of molecular weight}

To purify D-enzyme from Nostoc the soluble cell fraction was prepared after Bogner et al. (1993) except that the cells were ruptured by ultrasonic treatment (30 min, Branson sonifier B-12 set at maximal sonic output); the final dialysis was against $20 \mathrm{~mm}$ potassium phosphate buffer $\mathrm{pH} 6.8$. Dialysate containing between 40 and $60 \mathrm{mg}$ protein was applied to a hydroxyl apatite column (length $30 \mathrm{~cm}$, diameter $2.2 \mathrm{~cm}$ ) and eluted with a gradient of potassium phosphate buffer from $20 \mathrm{~mm}$ $(\mathrm{pH}$ 6.8) to $1.1 \mathrm{M}(\mathrm{pH} 5.8)$. The flow rate was $1.25 \mathrm{ml} / \mathrm{min}$ and fractions of $5 \mathrm{ml}$ were collected. The active fractions were pooled, concentrated and the buffer exchanged against $20 \mathrm{~mm}$ imidazole $\mathrm{pH} / 6.8$ by ultrafiltration (Centriprep-30, Amicon). The purification proceeded with an anion exchange column (Mono Q HR 5/5 column, Pharmacia) run at $1 \mathrm{ml} / \mathrm{min}$ with a gradient from zero to $1.1 \mathrm{M} \mathrm{NaCl}$ in $20 \mathrm{~mm}$ imidazole $\mathrm{pH} 6.8$; the fraction size was $1.0 \mathrm{ml}$. Both columns were operated with the help of a FPLC chromatographic system (Pharmacia) at room temperature whereas all other operations (except cell breakage and initial centrifugations, see Bogner et al., 1993) were carried out at $0-4{ }^{\circ} \mathrm{C}$. For purification of D-enzyme from Chlorella 3.83 the algal cells were washed once with $0.1 \mathrm{M}$ potassium phosphate buffer $(\mathrm{pH}$ 6.8), suspended in fresh buffer to give a density of $150 \mu \mathrm{l}$ packed cells $\cdot \mathrm{ml}^{-1}$ and were broken by two passages through a French press at $140 \mathrm{MPa}$. The homogenate was centrifuges at $48,000 \times g$ for $20 \mathrm{~min}$ and the resulting supernatant further at $113,000 \times g$ for $1 \mathrm{~h}$. The final supernatant was brought to $30 \%$ saturation of ammonium sulfate and, after removal of the greenish precipitate by centrifugation, was extensively dialysed against $20 \mathrm{~mm}$ imidazole $/ \mathrm{HCl} \mathrm{pH} \mathrm{6.8.} \mathrm{Further} \mathrm{purification}$ was achieved by column chromatography on hydroxyl apatite and anion exchange resin as described above. All procedures were carried out at $0-4{ }^{\circ} \mathrm{C}$ except for column chromatography.
The relative molecular mass of the D-enzyme from Nostoc and from Chlorella was estimated by gel filtration on a superose $12 \mathrm{HR} 10 / 30$ column (Pharmacia) run with $50 \mathrm{~mm}$ imidazole $/ \mathrm{HCl}$ $\mathrm{pH} 6.8$ at $0.4 \mathrm{ml} / \mathrm{min}$. As molecular weight standards were used apoferritin $(443 \mathrm{kDa}), \beta$-amylase $(200 \mathrm{kDa})$, aldolase $(160 \mathrm{kDa})$, bovine serum albumin $(67 \mathrm{kDa})$, ovalbumin $(45 \mathrm{kDa})$, cytochrome $c$ $(12.3 \mathrm{kDa})$ and vitamin B $12(1.36 \mathrm{kDa})$.

\section{Tests for enzymatic activity}

Activity of D-enzyme was routinely determined by incubating enzyme preparation in a total volume of $0.35 \mathrm{ml}$ at $30^{\circ} \mathrm{C}$ in the presence of $20 \mathrm{~mm}$ imidazole $/ \mathrm{HCl} \mathrm{pH} 6.8$ and $10 \mathrm{~mm}$ maltotriose. The reaction was stopped by heat $\left(95^{\circ} \mathrm{C}, 5 \mathrm{~min}\right)$ after $1 \mathrm{~h}$ and the control at time zero. Denaturated protein was removed by centrifugation and aliquots of the supernatant were assayed for glucose by an enzymatic test based on NADP-reduction mediated by hexokinase/glucose-6-phosphate dehydrogenase (Bergmeyer et al., 1974). Checks were made to be sure of linear kinetics with respect to incubation time and enzyme concentration.

Glucosidase activity was tested by incubating enzyme preparation in the presence of $20 \mathrm{~mm}$ imidazole $/ \mathrm{HCl} \mathrm{pH} 6.8$ with $1 \mathrm{~mm} p$-nitrophenyl- $\alpha$-Dglucoside as substrate in a total volume of $0.5 \mathrm{ml}$ for $1 \mathrm{~h}$ at $30^{\circ} \mathrm{C}$. The reaction was terminated by addition of $1.0 \mathrm{ml} 0.2 \mathrm{M}$ sodium borate buffer $\mathrm{pH}$ 9.8 and the absorption of the $p$-nitrophenol formed was read at $405 \mathrm{~nm}$. Activity of amylase was measured with the dinitrosalicylic acid reagent as described previously (Bogner et al., 1974).

\section{Determination of protein}

Protein was determined as by Lowry et al. (1951) and, for samples of low $(1-12 \mu \mathrm{g})$ content, as given by Smith et al. (1985).

\section{Analysis of reaction products}

After heat stop and removal of precipitated protein the reaction mixtures were desalted with ion exchange resins (Serdolit CS-2 and AS 6, Serva, Heidelberg, F.R.G.), concentrated under reduced pressure and subjected to thin-layer chromatography on silica gel sheets. Chromatograms were developed twice in acetone $/ n$-butanol $/$ water $=$ $70 / 15 / 15(\mathrm{v} / \mathrm{v})$ and stained with alkaline $\mathrm{KMnO}_{4}$. 
Radioactive spots were detected with a TLC-scanner (LB 284 from Berthold, Wildbad, F.R.G.).

\section{Preparation of $\left[{ }^{14} \mathrm{C}\right]$ maltotriose}

$\left[{ }^{14} \mathrm{C}\right]$ maltotriose was prepared by incubating D- $\left[{ }^{14} \mathrm{C}\right]$ glucose and soluble starch in the presence of D-enzyme as described in the legend to Fig. 4B followed by thin-layer-chromatographic separation (see above). The position of the label in maltotriose was determined by reduction with $\mathrm{NaBH}_{4}$ followed by hydrolysis in trifluoroacetic acid. Thin-layer chromatography revealed glucitol as the sole radioactive reaction product indicating the label to reside in the reducing end of maltotriose.

\section{Results}

\section{D-Enzyme from Nostoc}

Purification of D-enzyme and isomaltase. When the soluble fraction of a Nostoc cell extract was incubated with maltotriose liberation of glucose was observed which, as will be shown later, was due to the action of D-enzyme. A first purification step on a hydroxylapatite column revealed a large activity peak which was used for further studies and a minor one which may be an isoform of D-enzyme (Fig. 1). Besides, at higher phosphate concentrations, a low activity hydrolyzing $p$-nitrophenyl- $\alpha-D-$ glucoside and isomaltose was encountered (Fig. 1). Isomaltase was enriched by hydroxylapatite chromatography (7-10-fold) with good yield, but, because of its low activity was not investigated further. From D-enzyme activity contaminating phycobiliproteids were effectively removed by anion exchange chromatography; no amylase activity could be detected in these preparations. In this stage of purification still around 20 protein bands could be discerned with the sensitive

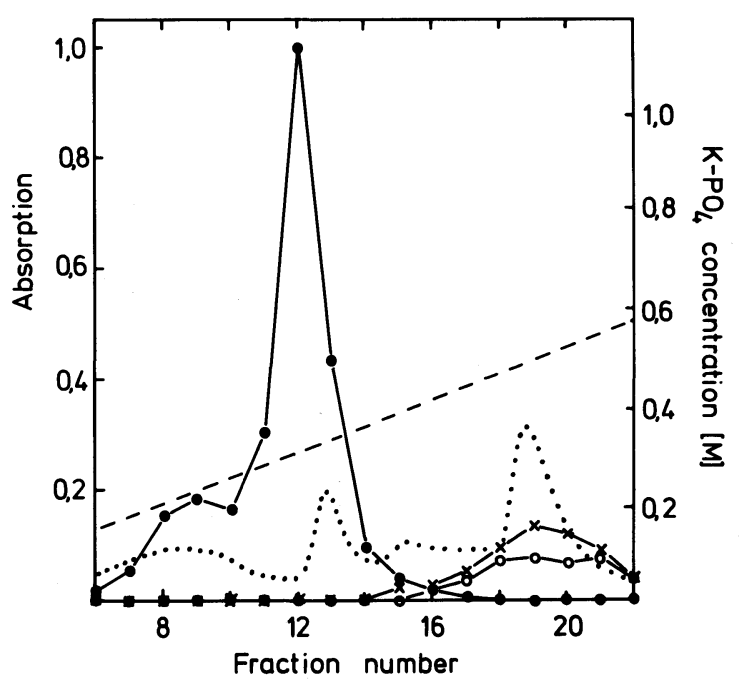

Fig. 1. Elution of D-enzyme activity $\left(\mathrm{A}_{340},-0\right)$, isomaltase $\left(\mathrm{A}_{340}, \mathrm{O}-\mathrm{O}\right), p$-nitrophenyl- $\alpha$-glucoside-cleaving activity $\left(\mathrm{A}_{405}, \mathrm{x}-\mathrm{x}\right)$ and protein $\left(\mathrm{A}_{280}, \cdots \cdots\right)$ from a hydroxylapatite column by a potassium phosphate buffer gradient $(----)$. The soluble fraction of a Nostoc homogenate originating from $11.7 \mathrm{~g}$ wet weight filaments was applied to the column. The maximum activities were 2.13 and $0.043 \mu \mathrm{mol} / \mathrm{h} \cdot \mathrm{ml}$ fraction for D-enzyme and isomaltase, respectively.

silver stain technique after SDS/polyacryl amide gel electrophoresis. A typical purification scheme is presented in Table I. In the following experiments D-enzyme purified by two column chromatographic steps was routinely used.

Product analyses and substrate specificity. After enzyme action on $\left[{ }^{14} \mathrm{C}\right]$ maltotriose, thin-layerchromatographic analysis revealed glucose and maltopentaose as main reaction products besides smaller amounts of higher maltooligosaccharides (Fig. 2A). Both, glucose and maltopentaose, were radioactive reaction products formed from maltotriose labeled in the reducing end; this indicates a

Table I. Enrichment of D-enzyme activity from $7.7 \mathrm{~g}$ wet weight Nostoc filaments by column chromatography.

\begin{tabular}{lllll}
\hline Fraction & $\begin{array}{l}\text { Protein content } \\
{[\mathrm{mg}]}\end{array}$ & $\begin{array}{l}\text { Specific activity } \\
{[\mu \mathrm{mol} / \mathrm{h} \cdot \mathrm{mg} \text { protein }]}\end{array}$ & $\begin{array}{l}\text { Yield } \\
{[\%]}\end{array}$ & Purification \\
\hline $\begin{array}{l}\text { Homogenate (dialyzed soluble fraction) } \\
\begin{array}{l}\text { Hydroxylapatite chromatography, } \\
\text { fractions 12 and 13 }\end{array}\end{array}$ & 33.0 & 0.57 & 100 & 1 \\
$\begin{array}{l}\text { Anion exchange chromatography, } \\
\text { fractions 11 and 12 }\end{array}$ & 3.80 & 2.54 & 52 & 4.5 \\
\hline
\end{tabular}




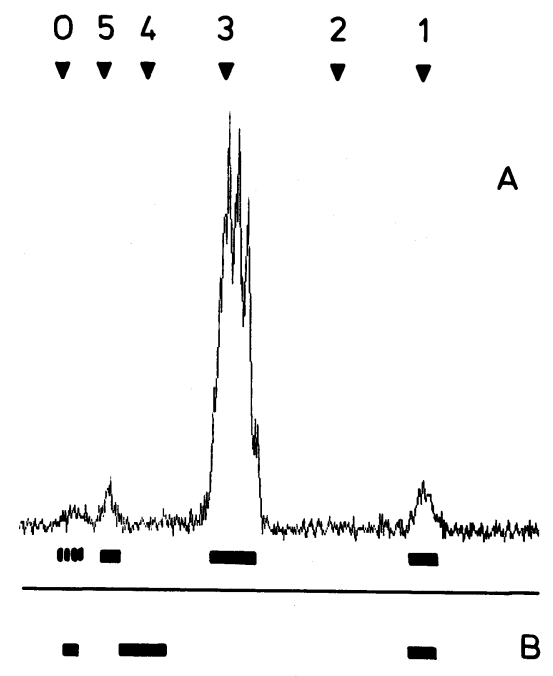

Fig. 2. Thin-layer-chromatographic analysis of a digest of (A) $\left[{ }^{14} \mathrm{C}\right]$ maltotriose and (B) maltotetraose by D-enzyme from Nostoc. The original incubation mixture contained $10 \mathrm{~mm}$ oligosaccharide substrate, $20 \mathrm{~mm}$ imidazole $/ \mathrm{HCl} \mathrm{pH} 6.8$ and D-enzyme preparation (43 and $7.4 \mu \mathrm{g}$ protein $/ \mathrm{ml}$ in (A) and (B), respectively). Specific radioactivity of maltotriose was $5.3 \cdot 10^{5} \mathrm{~Bq} / \mu \mathrm{mol}$. The incubation time was $1 \mathrm{~h}\left(30^{\circ} \mathrm{C}\right)$; for further details see Materials and Methods. At the top are given the positions of the origin (0) and of reference substances $(1=$ glucose, $2=$ maltose, $3=$ maltotriose etc. $)$. Stained regions are indicated by bars, weak staining by a broken bar.

disproportionation took place by transfer of a maltosyl group containing the nonreducing end of the donor maltotriose to another maltotriose molecule according to the following scheme:

$$
\begin{aligned}
& \mathrm{G}-\mathrm{G}-\mathrm{G}_{\mathrm{r}}^{*}+\mathrm{G}-\mathrm{G}-\mathrm{G}_{\mathrm{r}}^{*} \rightarrow \mathrm{G}_{\mathrm{r}}^{*}+\mathrm{G}-\mathrm{G}-\mathrm{G}-\mathrm{G}-\mathrm{G}_{\mathrm{r}}^{*} \\
& \left(\mathrm{G}=\alpha-\mathrm{D}-\mathrm{Glucose} ; \mathrm{G}_{\mathrm{r}}^{*}=\right.\text { reducing end unit, } \\
& \left.{ }^{14} \mathrm{C} \text {-labeled }\right)
\end{aligned}
$$

Maltotetraose yielded glucose and oligosaccharides with a DP $>6$ as reaction products (Fig. 2B); in no case was observed the production of maltose. These patterns of action are characteristic of a disproportionating transglycosylase for which cleavage of the bond at the nonreducing end and of the bond penultimate to the reducing end are "forbidden" [cf. Peat et al., 1956; Jones and Whelan, 1969).

When the Nostoc enzyme was incubated with soluble starch and $\mathrm{D}-\left[{ }^{14} \mathrm{C}\right]$ glucose, radioactive maltooligosaccharides with a DP $\geq 3$ and only traces of maltose were formed (data not shown; similar to Fig. 4 B). This shows glucose to be an acceptor for maltosyl- and oligosaccharyl residues derived from starch through the action of D-enzyme, similar as with the D-enzyme from other sources (Walker and Whelan, 1957; Lin and Preiss, 1988).

The highest rates of glucose formation were observed with maltotriose as substrate, followed by higher maltooligosaccharides. Attack of cellotriose, disaccharides, glycogen and starch was not detectable except for a very slow cleavage of maltose (Table II). A similar pattern of specificity was observed in the raw soluble fraction of Nostoc, which contained neither an appreciable maltase nor invertase activity. A relatively low maltase activity was observed also in Anabaena (compare Table IV).

Properties of D-enzyme. D-enzyme activity had a broad $\mathrm{pH}$ optimum around $\mathrm{pH} 7.4$ (half maximal values at $\mathrm{pH} 5.7$ and $\mathrm{pH} 8.8$ ) with maltotriose as substrate and a similar one with maltoheptaose (data not shown). Differences with these substrates, however, were seen in the temperature dependence; maximal rates were attained around $40{ }^{\circ} \mathrm{C}$ and $45^{\circ} \mathrm{C}$ with maltotriose and maltoheptaose, respectively (data not shown). A $K_{\mathrm{M}}$ value of $5.5 \mathrm{~mm}$ was found for maltotriose and a somewhat lower value $(2.6 \mathrm{~mm})$ for the analogous heptaose (Fig. 3A). No significant effect on enzyme

Table II. Substrate specificity of the D-enzyme from Nostoc and from Chlorella 3.83 in catalyzing glucose release. Concentration of oligo- and disaccharides was $10 \mathrm{~mm}$ and that of starch (soluble Zulkowsky starch, Merck) and of glycogen (from oyster, type II, Sigma) was $1 \%(\mathrm{w} / \mathrm{v})$. Other conditions are given under Materials and Methods. A glucose release of $100 \%$ correspond-

\begin{tabular}{|c|c|c|}
\hline Substrate & \multicolumn{2}{|c|}{ Glucose release $[\%]$} \\
\hline Maltose & 1.5 & n.d. \\
\hline Maltotriose & 100 & 100 \\
\hline Maltotetraose & 74 & 78 \\
\hline Maltoheptaose & 27 & 45 \\
\hline Isomaltose & n.d. & n.d. \\
\hline Sucrose & n.d. & n.d. \\
\hline Cellotriose & n.d & n.d. \\
\hline Starch & n.d. & n.d. \\
\hline Glycogen & n.d. & n.d. \\
\hline
\end{tabular}
ed to 11.9 and $200.0 \mu \mathrm{mol} / \mathrm{h} \cdot \mathrm{mg}$ protein for the enzyme from Nostoc and Chlorella, respectively.

n.d. $=$ not detected. 


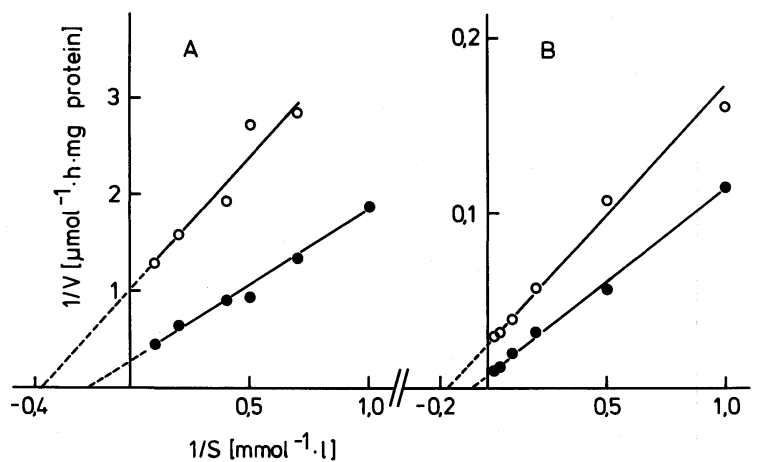

Fig. 3. Lineweaver-Burk plot of substrate dependence of D-enzyme activity from Nostoc (A) and from Chlorella 3.83 (B). Substrates were maltotriose (-O) and maltoheptaose $(\mathrm{O}-\mathrm{O})$.

activity had the presence of either of the following: $\mathrm{MgCl}_{2}, \mathrm{CaCl}_{2}$, EDTA (1 mM each). Gel filtration indicated an apparent molecular weight of $50 \mathrm{kDa}$ for the D-enzyme.

\section{D-Enzyme from Chlorella 3.83}

Purification. With ammonium sulfate $(30 \%$ saturation) practically all of the green material of the soluble cell fraction could be precipitated giving a slight enrichment on a protein basis (Table III). Precipitation at higher ammonium sulfate concentration caused large losses of activity and was not employed therefore. In the following chromatography on hydroxylapatite principally two elution patterns of D-enzyme activity could be discerned: either all of the activity eluted at low phosphate concentration $(0.20 \mathrm{M})$ or the activity split in two peaks, one eluting at the low phosphate concentration and the second one at higher concentration
$(0.30 \mathrm{M})$. This is considered to be due to subtle alterations in the state of the enzyme (for still unknown reasons) since e.g. in rechromatography the second peak eluted at the position of the first one and since in one preparation both types of activity profiles were registered in two adjacent runs. For further purification all of the active fractions were pooled and subjected to anion exchange chromatography. After this step an enrichment between 25- and 70-fold was achieved in five different preparations with yields ranging from 27 to $67 \%$ (see Table III). In anion exchange chromatography as well as in a following gel filtration run D-enzyme activity always eluted in one single peak (data not shown). After the gel filtration step hardly measurable amounts of protein were contained in the active fraction in which, after SDS/polyacryl amide gel electrophoresis and silver staining, still 12 protein bands were detectable. For the following analyses enzyme preparations purified according to the scheme in Table III were used throughout.

Product analyses and substrate specificity. When maltotriose was offered as substrate, only glucose and maltopentaose were detected as early reaction products and, after longer incubation, homologous maltooligosaccharides and in no case maltose. As with the corresponding enzyme of Nostoc maltopentaose formation was achieved by transfer of a maltosyl group from the nonreducing side of the maltotriose molecule [cf. Fig. 2]. From maltoheptaose appeared as first reaction products glucose and maltooligosaccharides with a DP $>6$ and, after prolonged incubation, also shorter homologues whereas maltose was undetectable (data not shown).

Table III. Purification of D-enzyme from $5.2 \mathrm{ml}$ packed cells of Chlorella 3.83. Fraction 12 of anion exchange chromatography eluted at $0.48 \mathrm{M} \mathrm{NaCl}$.

\begin{tabular}{llccc}
\hline Fraction & $\begin{array}{l}\text { Protein content } \\
{[\mathrm{mg}]}\end{array}$ & $\begin{array}{l}\text { Specific activity } \\
{[\mu \mathrm{mol} / \mathrm{h} \cdot \mathrm{mg} \text { protein }]}\end{array}$ & $\begin{array}{l}\text { Yield } \\
{[\%]}\end{array}$ & Purification \\
\hline $\begin{array}{l}\text { Homogenate (dialyzed soluble fraction) } \\
\begin{array}{l}\text { Ammonium sulfate fractionation, } \\
\text { supernatant after 30\% saturation }\end{array}\end{array}$ & 144 & 1.50 & 100 & 1 \\
$\begin{array}{l}\text { Hydroxylapatite chromatography, } \\
\text { pooled active fractions }\end{array}$ & 95.9 & 2.03 & 90 & 1.36 \\
$\begin{array}{l}\text { Anion exchange chromatography, } \\
\text { fraction 12 }\end{array}$ & 26.8 & 6.17 & 76 & 4.11 \\
\hline
\end{tabular}


Besides maltotriose (see above) glucose served as an acceptor in transglycosylation, too. This was seen when a mixture of maltotriose and labeled glucose was incubated with the enzyme: the predominant labeled reaction product was maltotriose (Fig. 4A). In an analogous experiment soluble starch instead of maltotriose was successfully used as donor substrate, resulting in a higher percentage of larger maltooligosaccharides (DP $\geq 4$ ) in the reaction products (Fig. 4B) which probably is due to considerable maltooligosaccharyl transfer directly from starch to glucose. All of these characteristics are in agreement with those reported for D-enzyme from Nostoc (see above) and from higher plants (Peat et al., 1956; Jones and Whelan, 1969; Manners and Rowe, 1969; Walker and Whelan, 1957).

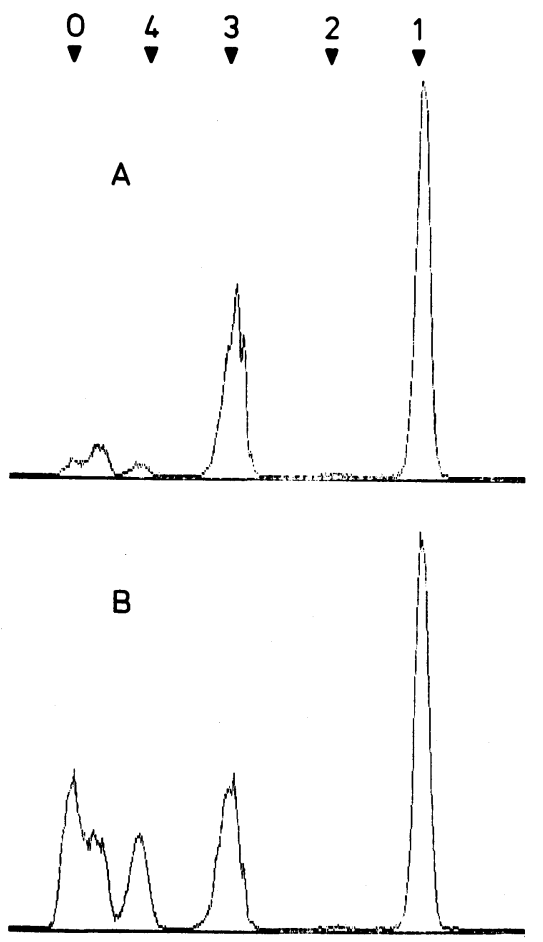

Fig. 4. Thin-layer-chromatographic analysis of the products formed by transglycoslase from Chlorella 3.83 with $\mathrm{D}-\left[{ }^{14} \mathrm{C}\right]$ glucose as acceptor and $(\mathbf{A})$ maltotriose or $(\mathbf{B})$ starch as donor. The incubation mixture contained $10 \mathrm{mM} \mathrm{D}-\left[{ }^{14} \mathrm{C}\right]$ glucose $\left(2.94 \cdot 10^{8} \mathrm{~Bq} / \mu \mathrm{mol}\right), 14 \mathrm{~mm}$ imidazole $/ \mathrm{HCl} \mathrm{pH} 6.8$, D-enzyme preparation $(0.7 \mathrm{mg}$ protein $/ \mathrm{ml}$ ) and either $10 \mathrm{~mm}$ maltotriose $(\mathbf{A})$ or $82.5 \mathrm{mg} / \mathrm{ml}$ soluble starch $(\mathbf{B})$. The incubation time was $1 \mathrm{~h}\left(30^{\circ} \mathrm{C}\right)$. For further details see Materials and Methods. Positions of reference substances are indicated as in Fig. 2.
When D-enzyme acted on maltodextrins the rate of released glucose fell with the chain length of the substrate and was not detectable for disaccharides, cellotriose, starch and glycogen (Table II). This is essentially the same substrate dependence as found for the D-enzyme from Nostoc (Table II) and from Arabidopsis (Lin and Preiss, 1988).

Properties of D-enzyme. The enzyme showed maximal action around $\mathrm{pH} 7.2$ and more than $80 \%$ of this activity between $\mathrm{pH} 6.0$ and $\mathrm{pH} 8.4$. At $\mathrm{pH} 4.8$ the activity had dropped to $6 \%$ and at $\mathrm{pH} 9.6$, depending on the buffer used, to $71 \%$ (glycine $/ \mathrm{NaOH}$ ) or $11 \%$ (1,3-bis[tris(hydroxymethyl)methylamino]propane). The temperature optimum of D-enzyme activity was located at $49.5^{\circ} \mathrm{C}$ with a steep decline towards higher temperatures $\left(30 \%\right.$ activity at $\left.57{ }^{\circ} \mathrm{C}\right)$ and was similar for maltotriose and maltoheptaose (data not shown). For the latter substrate a $K_{\mathrm{M}}$ of $5.9 \mathrm{~mm}$ was determined and for maltotriose a somewhat higher value (14.2 mM; Fig. 3 B). No significant effect on enzyme activity was noticed by the addition of each of the following: $\mathrm{MgCl}_{2}, \mathrm{CaCl}$ and EDTA (1.0 mM final concentration). An apparent molecular weight of $230 \mathrm{kDa}$ was estimated for $\mathrm{D}$-enzyme by gel filtration which is an almost five-fold higher value than found for the respective enzyme from Nostoc.

Occurrence of D-enzyme in free-living cyanobacteria and green algae

Anabaena PCC 7120, Chlorella kessleri and Chlamydomonas noctigama were tested for the presence of D-enzyme. With all three organisms the soluble fraction of a cell homogenate readily catalyzed liberation of glucose when maltotriose or maltotetraose were offered as a substrate (Table IV). This should not be due to the action of $\alpha$-amylase since maltotriose is no (Whelan et al., 1953) or only a poor (Meyer and Gonon, 1951) substrate for this enzyme; besides, EDTA was hardly inhibitory (Table IV) dismissing the involvement of Ca-requiring $\alpha$-amylases. A $\beta$-amylase obviously does not participate either since maltotriose is an extremely poor substrate for it and since it should not produce glucose from maltotetraose (Whelan et al., 1953). Maltose was cleaved very slowly suggesting only a limited role of $\alpha$-glucosidase. Thin-layer chromatography of the digest of maltotriose revealed for all species glu- 
Table IV. Glucose release by the soluble cell fraction of Anabaena and two species of green algae with the substrates maltose, maltotriose and maltotetraose. Cell breakage and centrifugations were as described for the purification of D-enzyme from Chlorella 3.83; activity tests were as the one routinely used for D-enzyme (see Materials and Methods) but with substrates as listed below. A relative rate of $100 \%$ corresponded to $2.09,2.41$ and $4.89 \mu \mathrm{mol} / \mathrm{h} \cdot \mathrm{mg}$ protein in Anabaena, Chlorella and Chlamydomonas, respectively.

\begin{tabular}{llll}
\hline Substrate $[10 \mathrm{~mm}]$ & Maltose Maltotriose & $\begin{array}{l}\text { Maltotriose } \\
5 \mathrm{~mm} \text { EDTA }\end{array}$ & Maltotetraose \\
\hline
\end{tabular}

Rate of glucose release [\%]

Organism

$\begin{array}{lrrrr}\text { Anabaena } \text { PCC 7120 } & 4.3 & 100 & 101 & 73 \\ \text { Chlorella kessleri } & 9.5 & 100 & 90 & 83 \\ \text { Chlamydomonas noctigama } & 9.6 & 100 & 93 & 36\end{array}$

cose, maltopentaose and some higher maltodextrins as reaction products, but never maltose (data not shown). This all is taken as evidence for the occurrence of D-enzyme in cyanobacteria and green algae.

\section{Discussion}

The pattern of reaction products formed from maltooligosaccharides by D-enzyme from Nostoc and Chlorella agrees well with that reported for D-enzyme from different higher plants (Peat et al., 1956; Jones and Whelan, 1969; Manners and Rowe, 1969; Lin and Preiss, 1988). An exception to the present work and other results (Peat et al., 1956; Jones and Whelan, 1969; Manners and Rowe, 1969) is the early formation of maltotriose and glucose from maltotetraose by the enzyme from Arabidopsis (Lin and Preiss, 1988) instead of the commonly observed products maltoheptaose and glucose. The ability of disproportionating transglycosylase to transfer maltosyl- and maltodextrinyl residues to glucose as acceptor (see Fig. 4) confirms previous data on this reaction (Manners and Rowe, 1969; Walker and Whelan, 1957; Lin and Preiss, 1988). Obviously, the reactions catalyzed by D-enzyme from as different groups as cyanobacteria, green algae and higher plants are in general quite uniform. Considerable differences relate, however, to other characteristics of D-enzyme from the various sources; e.g. the molecular weight was $50 \mathrm{kDa}$ (Nostoc) or $230 \mathrm{kDa}$ (Chlorella), temperature optima were found at $50{ }^{\circ} \mathrm{C}$ (Chlorella) or $37^{\circ} \mathrm{C}$ (Rowe and Manners, 1969) and pH optima were encountered at pH 7.4 (Nostoc), pH 6.7 (Peat et al., 1956) or $\mathrm{pH} 5.4$ (Rowe and Manners, 1969). Isoforms of the enzyme have been found (Lin and Preiss, 1988) and are also indicated for Nostoc ( $c f$. Fig. 1).

Disproportionating transglycosylase occurs in cyanobacteria and green phototrophs most of which synthesize $\alpha$-glucans as reserve carbohydrate. Thus, the suggested function of D-enzyme in assisting phosphorolytic breakdown of starch (Lee et al., 1970) seems reasonable for these organisms. In the symbiotic Nostoc, however, another role of D-enzyme may be to provide from oligosaccharides free glucose which in the intact lichen is known to move to the fungal partner (Drew and Smith, 1967; Hill and Smith, 1972). This pathway appears unsatisfactory at first sight since with each glucose liberated an elongated maltodextrin is generated, which, when grown too long for D-enzyme attack, had to be cut down again by amylolysis or phosphorolysis. Alternative ways of glucose formation, however, seem problematic too; for glucose phosphate as precursor a specific phosphatase had to be assumed and cleavage of maltose and sucrose is negligible in Nostoc extracts. A glucosidase hydrolyzing $p$-nitrophenyl $\alpha$-D-glucoside has been reported from Nostoc (Bogner et al., 1993); this enzyme probably is an isomaltase as suggests the similar elution behaviour in hydroxylapatite chromatography (Fig. 1). Because of its low activity and a relatively low substrate level in vivo it should liberate only limited amounts of glucose. To clarify the actual way of glucose for- 
mation experiments should be undertaken with the freshly isolated cyanobiont which in many respects differs from the cultivated from (Green and Smith, 1974).

Bergmeyer H. U., Bernt E., Schmidt F. and Stork H. (1974), D-Glucose: Bestimmung mit Hexokinase und Glucose-6-phosphat-Dehydrogenase. In: Methoden der enzymatischen Analyse (H. U. Bergmeyer, ed.), Verlag Chemie, Weinheim, pp. 1241-1246.

Bogner E., Wastlhuber R., Schlegl I. and Loos E. (1993), Glycogen, amylase and $\alpha$-glucosidase as possible components in the glucose release system of the cyanobiont of Peltigera horizontalis. Partial purification and characterization. Symbiosis 14, 485-494.

Drew E. A. and Smith D. C. (1967), Studies in the physiology of lichens VIII. Movement of glucose from alga to fungus during photosynthesis in the thallus of Peltigera polydactyla. New Phytol. 66, 389-400.

Fischer A., Meindl D. and Loos E. (1989), Glucose excretion by the symbiotic Chlorella of Spongilla fluviatilis. Planta 179, 251-256.

Green G. A. and Smith D. C. (1974), Lichen physiology. XIV. Differences between lichen algae in symbiosis and in isolation. New Phytol. 73, 753-766.

Hill O. J. and Smith D. C. (1972), Lichen physiology. XII. The "inhibition technique". New Phytol. 71, $15-30$.

Jones G. and Whelan W. J. (1969), The action pattern of D-enzyme, a transmaltodextrinylase from potato. Carbohyd. Res. 9, 483-490.

Kakefuda G., Duke S. H. and Hostak M. S. (1986), Chloroplast and extrachloroplast starch-degrading enzymes in Pisum sativum L. Planta 168, 175-182.

Kuhl A. (1962), Zur Physiologie der Speicherung kondensierter anorganischer Phosphate in Chlorella. In: Beiträge zur Physiologie und Morphologie der Algen (Deutsche Botanische Gesellschaft, ed.), Fischer, Stuttgart, pp. 157-166.

Lee E. Y. C., Smith E. E. and Whelan W. J. (1970), Homologies in glycogen and starch metabolism. In: Homologies in Enzymes and Metabolic Pathways/ Metabolic Alterations in Cancer (W. J. Whelan and J. Schultz, eds.), North Holland Publishing Company, Amsterdam, pp. 139-150.

Lin T. and Preiss J. (1988), Characterization of D-enzyme (4- $\alpha$-Glucanotransferase) in Arabidopsis leaf. Plant Physiol. 86, 260-265.

Lowry O. H., Rosebrough N. J., Farr A. L. and Randall R. J. (1951), Protein measurement with the folin phenol reagent. J. Biol. Chem. 193, 265-275.

\section{Acknowledgement}

This work was supported by the Deutsche Forschungsgemeinschaft. Thanks are due to Dr. Iris Maldener for critical reading of the manuscript.

Manners D. J. and Rowe K. L. (1969), Studies on carbohydrate-metabolizing enzymes. The $\alpha$-glucosidase and D-enzyme activity of extracts of carrots and tomatoes. Carbohyd. Res. 9, 441-450.

Matzke B., Schwarzmeier E. and Loos E. (1990), Maltose excretion by the symbiotic Chlorella of the heliozoan Acanthocystis turfacea. Planta 181, 593-598.

Meindl D. and Loos E. (1990), Release of glucose by Nostoc spec. isolated from the lichen Peltigera horizontalis. Plant Science 72, 283-288.

Meyer K. H. and Gonon W. F. (1951), La dégradation de l'amylose par les amylases. Recherches sur l'amidon 50. Helv. Chim. Acta 34, 294-307.

Okita T. W., Greenberg E., Kuhn D. N. and Preiss J. (1979), Subcellular localization of starch degradative and biosynthetic enzymes of spinach leaves. Plant Physiol. 64, 187-192.

Peat S., Whelan W. J. and Rees W. R. (1956), The enzymic synthesis and degradation of starch. Part XX. The disproportionating enzyme (D-enzyme) of potato. J. Chem. Soc., 44-53.

Smith P. K., Krohn R. J., Hermanson G. T., Mallia A. K., Gartner F. H., Provenzano M. D., Fujimoto E. K., Goeke N. M., Olson B. J. and Klenk D. C. (1985), Measurement of protein using bicinchoninic acid. Anal. Biochem. 150, 76-85.

Stanier R. Y., Kunisawa R., Mandel M. and Cohen-Bazire G. (1971), Purification and properties of unicellular blue-green algae (order Chroococcales). Bacteriol. Rev. 35, 171-205.

Walker G. J. and Whelan W. J. (1987), The mechanism of carbohydrase action. 4. The mechanism of D-enzyme action. Biochem. J. 67, 548-551.

Whelan W. J., Bailey J. M. and Roberts P. J. P. (1953), The mechanism of carbohydrase action. Part I. The preparation and properties of maltodextrin substrates. J. Chem. Soc., 1293-1298.

\section{Note added in proof}

A related report on D-enzyme has appeared recently: Takaha T., Yanase M., Okada S. and Smith S. M. (1993), Disproportionating enzyme (4- $\alpha$-glucanotransferase; EC 2.4.1.25) of potato. Purification, molecular cloning, and potential role in starch metabolism. J. Biol. Chem. 268, 1391-1396.

\section{$r$}

